\title{
Erratum to: Morphological Characterization and Hydrodynamic Behavior of Shortfin Mako Shark (Isurus oxyrinchus) Dorsal Fin Denticles
}

\author{
Patricia Fernandez-Waid ${ }^{1}$, Guzman Diez ${ }^{2}$, Iñigo Bidaguren ${ }^{3}$, Urtzi Izagirre ${ }^{1}$, \\ Jesus Maria Blanco ${ }^{3}$, Manu Soto ${ }^{{ }^{*}}$ \\ 1. Department of Zoology and Animal Cell Biology, Research Centre for Experimental Marine Biology and Biotechnology \\ (PiE-UPV/EHU), University of the Basque Country, Bilbao and Areatza z/g, Plentzia 48620, Bizkaia, Spain \\ 2. Marine Research Division, AZTI, Txatxarramendi s/n Sukarrieta 48395, Bizkaia, Spain \\ 3. Department of Nuclear Engineering and Fluid Mechanics, School of Engineering, (UPV/EHU) University of the Basque Country, \\ Plaza Ingeniero Torres Quevedo 1. 48013 Bilbao, Bizkaia, Spain
}

Copyright (C) 2019, Jilin University.

Erratum to: J Bionic Eng (2019) 16(4): 730-741

https://doi.org/10.1007/s42235-019-0059-7

The names of the authors were incorrect in the published paper and should be revised as "Patricia Fernandez-Waid, Guzman Diez, Iñigo Bidaguren, Urtzi Izagirre, Jesus Maria Blanco, Manu Soto".

The online version of the original article can be found at https://doi.org/10.1007/s42235-019-0059-7

\footnotetext{
*Corresponding author: Manu Soto

E-mail: manu.soto@ehu.eus
} 